\title{
Micro Financing Management and its Prospects: A Case Study Analysis on Bangladesh Perspective
}

\author{
Azmat Ullah ${ }^{1}$, Md Nazmul Haq ${ }^{2}$ \\ ${ }^{1}$ Lecturer, Department of Business Administration Port City International University, Chittagong, Bangladesh \\ ${ }^{2}$ Student of MPA in School of Public Affairs, Zijingang Campus, Zhejiang University, Hangzhou, PRC
}

\begin{abstract}
Microfinance's worldwide recognition has been credited to Prof. Dr. Muhammad Yunus who is the founder of the Grameen Bank in Bangladesh and recipient of the 2006 Nobel Peace Prize. Most microfinance studies in Bangladesh are limited to either one or two major MFIs or to the overall impact on clients' poverty reduction, improvement in health and social status, enhancement of women entrepreneurship and empowerment, etc. This study aims at understanding the management part of micro finance and its prospect of application in Bangladesh. The article also looks into the contribution of micro finance in Bangladesh economy together with sources of fund for such micro finance institutes.
\end{abstract}

Key words: $M F I$ 's, $N G O$ 's, SME's, Women Empowerment

\section{INTRODUCTION}

The story of microcredit can be fully understood only within the context of modern Bangladesh, where economic and social conditions have been improving. While income levels remain low, there has been steady growth of 5 to 6 percent for the past decade that raised incomes to $\$ 1,700$ (per capita gross domestic product [GDP] on purchasing power parity [PPP] basis) by 2012 .

Many rural households enjoy new income streams from family members working overseas, or in factory jobs in the rapidly expanding ready-made garments industry. Strong development fundamentals have positioned Bangladesh as one of the few low-income countries on target to achieve its Millennium Development Goals (MDGs) (The Economist 2012)

\section{LITERATURE REVIEW}

Microfinance's worldwide recognition has been credited to Muhammad Yunus who is the founder of the Grameen Bank in Bangladesh and recipient of the 2006 Nobel Peace Prize. Although microfinance was not his original idea, Yunus pioneered the implementation of group based lending and collateral free loan. As a consequence, the poor women are able to manage credit and organize microenterprises (Engler, 2009, p. 82).

He founded the Grameen Bank in the 1970s as an effort to ameliorate the destitute poverty that plagued his country (Yunus, 2007, p. 20). Grameen Bank has more than 1,000 branches and 6 million members. Besides, the loan repayment rate of Grameen Bank is 98 percent (Midgley, 2008, p. 471).

Nothing can stop an idea whose time has gone. And micro-finance is in a danger zone. It is a discredited model. It has raised more questions that it has answered. To think that we are going to alleviate poverty is a tall claim. Microfinance has promised more than it has actually delivered, created more problems than actually solved and continues to promise much more than what it actually puts on the ground' (Jairam Ramesh, Indian Rural Development Minister, 2012)

More recently concerns have been raised about the real value and impact of microfinance. In the last few years 'microfinance meltdowns' have been reported in Morocco, Nicaragua, Pakistan, Bosnia, Mexico and Lebanon, and most dramatically in the Indian state of Andhra Pradesh when the entire microfinance industry collapsed in late 2010, which was the context of the quote by the then Indian minister mentioned above (Bateman \& Chang, 2012). More disturbingly, inability to repay microfinance loans has also been linked to 'hundreds of suicides' among borrowers in India (Associated Press, 2012) and organ trafficking in Bangladesh (BBC, 2013).

Emerging research on base-of-pyramid (BoP) approaches to poverty reduction and empowerment of poor populations suggests that market based initiatives directed at impoverished communities can leverage their social capital to develop capabilities that could lift them out of poverty (Ansari et al., 2012)

Most microfinance studies in Bangladesh are limited to either one or two major MFIs or to the overall impact on clients' poverty reduction, improvement in health and social status, enhancement of women 
entrepreneurship and empowerment, etc. No studies in Bangladesh, to the best of the author's knowledge, have yet considered innovation and sustainable entrepreneurship development.

An empirical study in Bangladesh among the Grameen Bank borrowers (with credit) and nonborrowers (without credit), and concluded that the microcredit program helps rural women to reduce their poverty most. They found that the 'with credit' women have a much lower percentage of poverty in terms of its incidence (80\%), intensity (28\%), and severity (12\%) compared to the 'without credit' respondents $99 \%, 59 \%$, and 37\% respectively. Chowdhury, Mahmud, and Abed (1991) observed that the participants of the Bangladesh Rural Advancement Committee (BRAC) have more income, owned more assets, and earned more, as compared to the non-participants. Ahmed et al. (2011)

An empirical study of 120 households from six villages in Bangladesh and presented findings from the study of the Grameen Bank and the BRAC, two programs that provide credit to poor rural women in Bangladesh. The programs were found to have significant effects on eight different dimensions of women's empowerment. Such kinds of studies conducted on one or two particular MFIs may not be able to pay unbiased outcomes. Moreover, other studies focused on welfare impacts pay less attention to sustainable entrepreneurship development. Hashemi, Schuler, and Riley (1996)

As seen in a number of cases around the world, the consistent winners in the Microfinance 'game' are the lenders who charges exorbitant interest rates that sometimes reach up to $200 \%$ per annum. (Roodman, 2011)In most of the cases, the over indebtedness becomes the main hurdle of Microfinance, as the borrowers take further loans to repay the old ones. Failure to generate any income from the funds of Microcredit subsequently wraps themselves in layers of debt, and it has been the center of concern for MFI think tanks over the years. (Lascelles, Mendelson, Rozas, 2014)

Some of the most harsh critics also argue that the MFI is a very effective tool of political control, which has its' roots in the 'Containment strategy' of the US Government in Latin America, where the idea was to prevent people from subscribing to leftist movements by reframing poverty not as a political problem, but as a private problem. (Bateman, 2010).

\section{OBJECTIVES OF THE STUDY}

The main objective of the study is to provide an analytical presentation of the prospects of microfinance in Bangladesh context. The specific objectives of the study include the following:

i) Identifying the prospects of micro finance credit in Bangladesh.

ii) Analyzing the contribution of micro finance credit in Bangladesh.

iii) Evaluating the role of NGO's and MFI's and their source of fund for its operation.

\section{METHODOLOGY OF THE STUDY}

Source of Data: This article is based on information collected from various secondary sources including books on social business authored by Dr. Muhammad Yunus, different articles on social business, business ethics and social responsibility, and a few related websites.

Data Analysis: The analysis will be mainly based on description. In case of necessity, simple tabular presentations may appear. Statistical and econometric analyses are not feasible options due to the fact that the social business is a new concept and necessary data are not yet available.

\section{DEFINITION AND FEATURES OF MICRO FINANCE}

Microcredit is used to narrate small credits granted to optimum income individuals that are separated from the traditional banking system. It is an integral part of the broader microfinance industry, which offers not only loan, but also savings, insurance, and other basic financial services to the needy people. The term 'micro' originated from the relatively small amounts of money that are being borrowed or saved. The birth of 'modern' micro-finance is said to have occurred in the mid 1970s in rural Bangladesh. Prof. Dr. Muhammad Yunus, professor of economics at the University of Chittagong, was becoming disillusioned with the abstract theories based on economics that failed to demonstrate why so many poor people were starving in Bangladesh.

To find a desire solution, Prof. Dr. Muhammad Yunus began visiting local villages. In one nearby village, Jorba, he discovered a group of 42 women who made bamboo stools. Because of having lack of funds to purchase the raw materials themselves, they were tied into a cycle of debt with local traders with a high interest and who would lend them the money for the materials on the agreement that they would sell the stools at a price barely more than the raw materials. Yunus was astonished to find that the entire borrowing needs of the 42 women amounted to the equivalent of US\$27. He lent them the money by his own fund without interest of helping the women to sell their stools for a reasonable price and break out of the cycle of debt. 


\subsection{Grameen Bank Activities in Microcredit}

The Grameen Bank was inaugurated as "Village Bank", and at present it works in more than eightythousand villages over six million borrowers. Prof. Dr. Muhammad Yunus and Grameen, both were awarded the Nobel Peace Prize in 2006 for their activities with the poor people.

Microcredit programs in Bangladesh is implemented by NGOs, Grameen Bank, state-owned commercial banks, private commercial banks, and specialized programs of some ministries of Bangladesh government. In the microfinance sector as of June, 2014 total loan outstanding is around BDT 403 billion (including Grameen Bank, 10 Government project and Commercial Banks) savings BDT 237 billion. The total clients of this sector are 33.73 million (including 8.62 million clients from Grameen Bank) that increases whole economic development process of Bangladesh. Loan services of this sector can be classified into six major categories: i) general microcredit for small-scale self employment based activities, ii) microenterprise loans, iii) loans for ultra poor, iv) agricultural loans, v) seasonal loans, and vi) loans for disaster management. Credit amounts up to BDT 50,000 (fifty thousand) are usually considered as microcredit; credits above this amount are considered as microenterprise loans.

\subsection{Microfinance Institutions (MFIs)}

Micro-finance Institutions (MFIs) are the organizations that offer services and products to the poor people which are related in micro-finance. Different types are: savings and credit cooperatives, NGOs, programs established by international organizations, legally-recognized micro-finance institutions, and micro-finance banks, and their sizes greatly vary, from 100 clients to over 6 million clients for the largest. MFIs offer not only basic financial services but also savings accounts, loan products and insurance. Non-financial services like as education and training or specific programs also provided by MFIs to combat regional issues.

\subsection{NGO-MFIs Licensing System in Bangladesh:}

In August, 2006, the Microcredit Regulatory Authority (MRA) started by the Government that received applications from 4241 NGO-MFIs. But, around 1000 applications were found to be very small organizations that had fewer than 1000 borrowers or less than the BDT 4 million outstanding loans that is generally considered as the minimal initial operating assortment of an MFI to be sustainable. However, till June, 2014 MRA had approved licenses in favor of 742 NGOs and canceled licenses of 45 NGOs. There are another 45 applications under process for a final decision even though they are mostly small organizations but with some importance to become viable in course of time. Total 3454 applications have been rejected in June, 2014. Recently MRA has requested new applications for getting license to operate microcredit activities among which 179 institutions have been given initial approval.

\section{CONTRIBUTION OF MICRO FINANCE IN BANGLADESH}

Although the recession and crisis in microcredit sector in several countries, Bangladesh's microfinance sector reveals resilience and regular to contribute towards improvement of macroeconomic growth. In June 2012 total outstanding loan of this sector (only licensed MFIs) has increased by 21 percent from BDT 211 billion to BDT 257 billion in June, 2013 and 8 percent from June, 2013 to June, 2014 which is BDT 278 billion disbursed among 19.98 million poor people, aiding them to be self-employed and increasing whole economic enhancement process of the country. The total savings has also increased by 24 percent from BDT 75.20 billion in June 2012 to BDT 93.99 billion in June 2013 and 20 Percent from June, 2013 for June, 2014 which is BDT 299 billion among 25.17 million clients.

TABLE-1: BASIC STATISTICS OF NGO-MFIS IN BANGLADESH

\begin{tabular}{|l|l|l|l|l|l|}
\hline Particulars & June,2010 & June, 2011 & June, 2012 & June, 2013 & June, 2014 \\
\hline No. of Licensed NGO-MFIs & 516 & 576 & 590 & $649^{*}$ & $676^{*}$ \\
\hline No of Branches & 17,252 & 18,066 & 17,977 & 14,674 & 16,991 \\
\hline No. of Employees & 109,597 & 111,828 & 108,654 & 110,734 & 114,644 \\
\hline No. of Clients (Million) & 25.28 & 26.08 & 24.64 & 24.60 & 25.17 \\
\hline No. of borrowers (Million) & 19.21 & 20.65 & 19.31 & 19.27 & 19.98 \\
\hline $\begin{array}{l}\text { Amount of Loan Outstanding } \\
\text { (BDT. Million) }\end{array}$ & $145,022.66$ & $1,73,797.60$ & 211,283 & 257,010 & 278,017 \\
\hline $\begin{array}{l}\text { Amount of Savings (BDT. } \\
\text { Million) }\end{array}$ & $51,362.93$ & $63,304.44$ & 75,206 & 93,990 & 112,991 \\
\hline
\end{tabular}

*Total Licensed NGO-MFIs was 697 but only 676 submitted MIS report.

Source: MRA-MIS Database-2014 
TABLE 1 shows the overall trend of microfinance statistics in Bangladesh. This sector has created direct job opportunities for over 114,644 people at June 2014; 81 percent of them are male and 19 percent are female. The sector had outstanding loans of BDT 278 billion disbursed to 19.98 million borrowers, and had accumulated BDT 112 billion as savings from around 25.17 million clients - over 93 percent of them are women - through more than 16,000 branches, by 676 NGO-MFIs licensed by MRA. 7.0 Operations and management of Micro Finance in Bangladesh.

\section{FUTURE PROSPECT OF MICRO FINANCE IN BANGLADESH}

In present years micro-finance has become a potential sources of innovations and experiments, from leveraging the vast popular mobile banking sector, by which mobile phones are used to receive and send money, for the objectives of micro-finance; to the introduction of new loan products converted to local contexts, like as harvest stock spaces, cattle fattening loans and machinery loans,.

Loan systems have also diversified, and the original model of supportive group loans pioneered by the Grameen Bank, which have become more ambiguous and adapted to local prospective. Currently, products such as micro-insurance and micro-savings, which earlier took the back-seat to micro-credit, are observing their popularity increase. The prospect of micro-finance is complex to assume, but several estimates recommend that 500 million to 1,5 billion people still lack enter to financial services that could strengthen their economic position and enhance their standard of life. After ten to twenty years 2.5 billion young people will become older, and it seems uncertain whether the conventional working market will be able to pick such demographic boom. The contribution of micro-finance and other alternatives ways to foster and assist auto-entrepreneurship are likely to remain crucial in the world market economy.

\subsection{Microcredit Interest Rates}

Micro-finance is based on the notion of running away from traditional help towards a viable and sustainable industrial sector; therefore interest charges are mandatory to cover the costs of administering the loans. The interest rates applied by micro-finance institutions are often considerably higher than those offered by conventional financial institutions. Because the cost of administering many small loans in rural areas is much higher than the cost of administering fewer large loans in developed urban circumstances.

To normal operational costs, the interest rates must be able to cover:

a. Costing of fund to the MFI - often higher in developing countries, as foreign funders will require a higher return to cover the additional risk of lending to micro-finance institutions.

b. Cost of administrative - compare the cost to your bank if you make a transaction at a branch or via the internet, versus the cost to an MFI of sending a loan officer weekly or monthly to collect repayments from a client in a rural village without a proper transport infrastructure. The latter is also likely to be a much smaller sum of money, making the transaction cost per euro or dollar much higher for the MFI.

c. Risk of exchange rate - of ten higher in developing countries; currencies may be volatile, illiquid, and inflation may be high.

d. High growth of default borrower - higher as borrowers can rarely offer collateral or credit history.

This does not mean that all high interest rates are acceptable. It is important that MFIs are adept and work to minimize their operating costs; this is something that the industry carefully scrutinizes, and as the extent of competition between MFIs grows, so does the force on them to minimize their interest rates.

So, how are micro-entrepreneurs to afford these interest rates? Several studies have been conducted in Mexico, and the Philippines, which have reveal that the \% (percentage) return on investment is much higher for microenterprises than larger businesses, finding rates ranging from $117 \%$ up to $847 \%$.

\subsection{Fund composition of the Microfinance sector in Bangladesh}

The sector is numerously financed by the following categories of sources: savings collected from clients, concessional loan received from sources such as PKSF, grants received from national and international donors, cumulative surplus (profit), and commercial bank borrowing. Table 2 reveals the last few years the fund composition of the microfinance sector in Bangladesh. While the total fund improved crucially over the time, there was only a little modify in terms of application of fund. In June, 2013 the total fund increased from BDT 136 billion to BDT 276 billion and the growth rate of 16-20 percent per year. Clients' savings is the most significant source of fund turned out which was the individual most significant fund support for the sector. The second most significant source of fund was cumulative surplus. The next more important one was loans from Commercial Banks. A microfinance wholesale funding agency like Loan from Palli Karma Sahayak Foundation (PKSF) also provides a big portion of loan fund at a subsidized rate. The donor agencies was appeared a little 
important source to be grants from as the previously donor driven NGOs are now trying to rely on local sources of fund with the reducing in foreign funding.

TABLE-2: SOURCE OF FUND OF NGO-MFIS IN BANGLADESH

\begin{tabular}{|c|c|c|c|c|c|c|c|c|c|c|}
\hline \multirow[t]{2}{*}{ Source of Fund } & \multicolumn{2}{|l|}{ June '10 } & \multicolumn{2}{|c|}{ June '11 } & \multicolumn{2}{|l|}{ June '12 } & \multicolumn{2}{|l|}{ June '13 } & \multicolumn{2}{|l|}{ June '14 } \\
\hline & $\begin{array}{l}\text { (Million } \\
\text { BDT) }\end{array}$ & $(\%)$ & $\begin{array}{l}\text { (Millio } \\
\text { n BDT) }\end{array}$ & $(\%)$ & $\begin{array}{l}\text { (Millio } \\
\text { n BDT) }\end{array}$ & $(\%)$ & $\begin{array}{l}\text { (Million } \\
\text { BDT) }\end{array}$ & $(\%)$ & $\begin{array}{l}\text { (Million } \\
\text { BDT) }\end{array}$ & $(\%)$ \\
\hline Clients' Savings & $\begin{array}{l}47,436.3 \\
5\end{array}$ & $\begin{array}{l}31.1 \\
5\end{array}$ & $\begin{array}{l}63,295 . \\
9\end{array}$ & $\begin{array}{l}34.4 \\
6\end{array}$ & $\begin{array}{l}74,989 . \\
36\end{array}$ & $\begin{array}{l}32.6 \\
2\end{array}$ & $\begin{array}{l}91,178.0 \\
1\end{array}$ & $\begin{array}{l}32.9 \\
5\end{array}$ & $\begin{array}{l}1,06,999 \\
.00\end{array}$ & $\begin{array}{l}34 . \\
4\end{array}$ \\
\hline Loan from PKSF & $\begin{array}{l}24,484.1 \\
2\end{array}$ & $\begin{array}{l}16.0 \\
8\end{array}$ & $\begin{array}{l}31,767 . \\
8\end{array}$ & 17.3 & $\begin{array}{l}33,576 . \\
45\end{array}$ & $\begin{array}{l}14.6 \\
1\end{array}$ & $\begin{array}{l}34,072.2 \\
7\end{array}$ & $\begin{array}{l}12.3 \\
1\end{array}$ & $\begin{array}{l}34,523.5 \\
0\end{array}$ & $\begin{array}{l}11 . \\
04\end{array}$ \\
\hline $\begin{array}{lr}\text { Loan } & \text { from } \\
\text { Commercial Banks }\end{array}$ & $\begin{array}{l}23,006.4 \\
1\end{array}$ & $\begin{array}{l}15.1 \\
1\end{array}$ & $\begin{array}{l}23,577 . \\
9\end{array}$ & $\begin{array}{l}12.8 \\
4\end{array}$ & $\begin{array}{l}32,652 . \\
41\end{array}$ & $\begin{array}{l}14.2 \\
0\end{array}$ & $\begin{array}{l}42,699.3 \\
7\end{array}$ & $\begin{array}{l}15.4 \\
3\end{array}$ & $\begin{array}{l}51,495.9 \\
0\end{array}$ & $\begin{array}{l}16 . \\
47\end{array}$ \\
\hline Donors' Fund & $4,109.29$ & 2.7 & $\begin{array}{l}70,08.3 \\
7\end{array}$ & 3.82 & $\begin{array}{l}7,061.2 \\
8\end{array}$ & 3.07 & $7,104.57$ & 2.57 & $6,855.04$ & $\begin{array}{l}2.1 \\
9\end{array}$ \\
\hline $\begin{array}{l}\text { Cumulative } \\
\text { Surplus }\end{array}$ & $\begin{array}{l}42,339.2 \\
7\end{array}$ & 27.8 & $\begin{array}{l}50,298 . \\
7\end{array}$ & $\begin{array}{l}27.3 \\
8\end{array}$ & $\begin{array}{l}65,437 . \\
78\end{array}$ & $\begin{array}{l}28.4 \\
7\end{array}$ & $\begin{array}{l}83,262.3 \\
8\end{array}$ & $\begin{array}{l}30.0 \\
9\end{array}$ & $\begin{array}{l}1,00,943 \\
.95\end{array}$ & $\begin{array}{l}32 . \\
28\end{array}$ \\
\hline Other Funds & $\begin{array}{l}10,907.4 \\
0\end{array}$ & 7.16 & $\begin{array}{l}7,727.3 \\
2\end{array}$ & 4.21 & $\begin{array}{l}16,167 . \\
91\end{array}$ & 7.03 & $\begin{array}{l}18,390.8 \\
9\end{array}$ & 6.65 & $\begin{array}{l}11,914.5 \\
8\end{array}$ & $\begin{array}{l}3.6 \\
2\end{array}$ \\
\hline Total & $\begin{array}{l}152,282 . \\
84\end{array}$ & $\begin{array}{l}100 . \\
00\end{array}$ & $\begin{array}{l}183,67 \\
6\end{array}$ & $\begin{array}{l}100 . \\
00\end{array}$ & $\begin{array}{l}229,885 \\
.2\end{array}$ & $\begin{array}{l}100 . \\
00\end{array}$ & $\begin{array}{l}276,707 . \\
48\end{array}$ & $\begin{array}{l}100 . \\
00\end{array}$ & $\begin{array}{l}312,731 . \\
97\end{array}$ & $\begin{array}{l}100 \\
.00\end{array}$ \\
\hline
\end{tabular}

Source: MRA-MIS Database-2014

Recently the commercial banks are considered a potential source of fund of microfinance by observing the MRA-MIS Database-2014, over the last three years their portion of the total source increased. MRA has been putting in efforts to increase loans from commercial banks to the sector by introducing the banks to the NGO-MFIs. However, due to high interest rate charged and inflation the borrowing cost from commercial banks is very high which is discouraged NGO-MFIs to avail this as a source of fund. Previously donor driven NGOs are now trying to rely more and more on local sources of fund with the reduce in foreign funding, which stood at only 2.19 percent in June 2014.

\subsection{Financial supporters}

Financial backers work as a catalyst, aiding new MFIs or micro-finance projects to initiate and grow their activities through investment or grants. The goal of institution to usually become self- sustained, but its takes years of investment before it become a reality. Private foundations and funders, such as Citigroup, Blue Orchard or Oikocredit as well as public institutions such as the European Commission, the World Bank are the financial backers of micro-finance institution.

\section{CONCLUSION}

Finally we can summarize that micro finance credit has greatly contributed to the economy of a developing country like Bangladesh. Poverty eradication, unemployment reductions, self-employment prospects together with self confidence and belief among poorest that they can also survive and contribute to the economy to build a nation. Micro credit financing to a lot extent have empowered women and at different villages in Bangladesh it is observed that the women are contributing a major portion of their income in their family. This not only increasing their social standings but a commitment to do even better in future. Smallest scale micro financing have enhanced in self realization and belief that one day these people can claim to have a SME (Small and Medium Enterprises) and thus coming forward in business supply chain position and contributing to the GDP (Gross Domestic Product) in Bangladesh. The concept of micro credit financing is a role model these days and proven to act as catalyst for poverty alienations together with employment growth and development of a sector of self employment work force who are motivated to do something on their own and contributing to a nation building prospects.

\section{REFERENCES}

[1]. Ahmed, F., C. Siwar, N. A. H. Idris, and R. A. Begum. 2011. "Microcredit's Contribution to the Socioeconomic Development amongst Rural Women: A Case Study of Panchagarh District in Bangladesh." African Journal of Business Management 5 (22): 9760-9769.

[2]. Ansari S, Munir K and Gregg T (2012) Impact at the "bottom of the pyramid": The role of social capital in capability development and community empowerment. Journal of Management Studies 49: 813-842 
[3]. Bateman M and Chang HJ (2012) Microfinance and the illusion of development: From hubris to nemesis in thirty years. World Economic Review 1: 13-36. BBC (2013) The Bangladesh poor selling organs to pay debts. http://www.bbc.co.uk/news/world-asia-24128096 (accessed 15 February 2016).

[4]. Jairam $\mathrm{R}$ (2012) Microfinance in danger zone. Outlook India. $\mathrm{ttp} / / / \mathrm{www}$.outlookindia.com/news/article/microfinance-in-danger-zone-jairam- ramesh/782055 (accessed 15 February 2016).

[5]. Midgley, J 2008, 'Microenterprise, global poverty and social development', International Social Work, Vol. 51, no.4, pp. 467-479.

[6]. Rahman, M. M, (2010), "Islamic Microfinance program and its impact on rural poverty alleviation, International Journal and Finance"

[7]. Roodman, David. (2011), "Does Compartamos charge 195\% interest?" Center for Global Development, Wachington D.C. 